\section{JURNAL EKONOMI EFEKTIF}

ISSN : $2622-8882$, E-ISSN : 2622-9935

Jurnal Ekonomi Efektif, Vol. 4, No. 2, Januari 2022

@Prodi Manajemen Fakultas Ekonomi

Universitas Pamulang

\title{
ANALISIS PENGARUH RETURN ON ASSET TERHADAP EARNING PER SHARE PADA PT MAYORA, TBK PERIODE 2011-2020
}

\author{
Sukristian Putra ${ }^{1}$, Masno Marjohan ${ }^{2 *}$ \\ Universitas Pamulang, Tangerang Selatan, Banten, Indonesia \\ sukristian0@gmail.com ${ }^{1}, \underline{\text { dosen00124@unpam.ac.id }{ }^{2 *}}$
}

Manuskrip: Desember-2021; Ditinjau: Desember-2021; Diterima: Desember-2021; Online: Januari -2022;

Diterbitkan: Januari-2022

\begin{abstract}
ABSTRAK
Penelitian ini bertujuan untuk mengetahui pengaruh Return On Asset terhadap Earning Per Share pada PT. Mayora, Tbk Periode 2011-2020. Metode yang digunakan adalah explanatory research. Teknik analisis menggunakan analisis statistik dengan pengujian regresi, korelasi, determinasi dan uji hipotesis. Hasil penelitian ini variabel Return On Asset diperoleh nilai rata-rata sebesar 8,40\%. Variabel Earning Per Share diperoleh nilai rata-rata 8801. Return On Asset berpengaruh positif dan signifikan terhadap Earning Per Share dengan nilai persamaan regresi $\mathrm{Y}=44,277+5,201 \mathrm{X}$, dan nilai koefisien korelasi 0,740 atau memiliki tingkat hubungan yang kuat dengan nilai determinasi sebesar 54,8\%. Uji hipotesis diperoleh signifikansi $0,014<0,05$.
\end{abstract}

Kata Kunci: Return On Asset, Earning Per Share

\section{ABSTRACT}

This study aims to determine the effect of Return On Assets on Earning Per Share at PT. Mayora, Tbk Period 2011-2020. The method used is explanatory research. The analysis technique uses statistical analysis with regression, correlation, determination and hypothesis testing. The results of this research variable Return On Assets obtained an average value of 8.40\%. Earning Per Share variable obtained an average value of 8801. Return on Assets has a positive and significant effect on Earning Per Share with a regression equation value of $Y=$ $44,277+5,201 X$, and a correlation coefficient value of 0.740 or has a strong relationship level with a determination value of 54, 8\%. Hypothesis testing obtained a significance of 0.014 $<0.05$.

Keywords: Return On Assets, Earning Per Share 


\section{PENDAHULUAN}

\section{A. Latar Belakang}

Di dalam dunia bisnis yang persaingannya semakin ketat, perusahaan harus bisa bersaing dengan perusahaan lainnya demi mendapatkan keuntungan semaksimal mungkin. Perusahaan harus berlomba demi mendapatkan masukan modal yang banyak dari luar untuk membantu kegiatan operasional perusahaan mereka, salah satunya dengan menjual saham. Begitupun dalam hal menjual saham tidak semudah yang kita kira, karena investor akan melihat laba per lembar saham (Earning per share) sebuah perusahaan dari tahun ke tahun, apakah meningkat stabil atau justru mengalami naik turun (fluktuasi). Investor akan lebih tertarik menanamkan modalnya ke perusahaan yang memiliki tingkat laba per lembar saham (Earning per share) tinggi dan juga stabil, begitupun sebaliknya. Jika (Earning per share) suatu perusahaan rendah dan juga terjadi fluktuasi, mungkin investor akan berfikir dua kali apakah mau menanamkan modalnya atau tidak.

Secara umum laba per lembar saham atau (Earning per share) diartikan sebagai tingkat keuntungan bersih untuk tiap lembar sahamnya yang mampu diraih sebuah perusahaan pada saat menjalankan operasinya. Menurut Kasmir (2012:207) menyatakan bahwa Earning Per Share merupakan "rasio untuk mengukur keberhasilan manajemen dalam mencapai keuntungan bagi pemegang saham". Pada umumnya para pemegang saham tertarik dengan Earning per share yang besar karena hal tersebut merupakan salah satu indikator keberhasilan perusahaan. Apabila Earning per share suatu perusahaan mengalami peningkatan, berarti laba perusahaan yang berarti juga peningkatan kekayaan bagi pemegang saham. Adapun beberapa faktor-faktor yang mempengaruhi Earning per share yakni rasio profitabilitas yang di proksikan dengan Return on Assets.

Rasio profitabilitas mengukur kemampuan perusahaan dalam menghasilkan suatu laba. Rasio profitabilitas dalam penelitian ini diwakili oleh Return on Assets (ROA). Rasio ini merupakan rasio yang menunjukkan tingkat persentase keuntungan laba yang diperoleh perusahaan terkait sumber daya atau total asset sehingga efisiensi suatu perusahaan dalam mengelola assetnya bisa terlihat dari persentase rasio ini. Rasio ROA semakin kurang baik jika rasio tersebut semakin kecil, begitupun sebaliknya.

Menurut I Made Sudana (2011:22) mengemukakan bahwa "Return on Assets (ROA) menunjukkan kemampuan perusahaan dengan menggunakan seluruh aktiva yang dimiliki untuk menghasilkan laba setelah pajak". Menurut Kasmir (2012:201) "Return on Assets merupakan rasio yang menunjukkan hasil (return) atas jumlah asset yang digunakan dalam perusahaan atau suatu ukuran tentang aktivitas manajemen”.

Dari pernyataan tersebut dapat disimpulkan bahwa Return on Assets (ROA) merupakan rasio yang menunjukkan seberapa banyak laba bersih yang yang bisa diperoleh dari seluruh kekayaan yang dimiliki perusahaan.

Berikut ini perkembangan Return on Assets (ROA) dan Earning Per Share (EPS) PT Mayora, Tbk, Periode 2011-2020 sebagai berikut:

Tabel 1. Perkembangan Return on Assets (ROA) dan Earning Per Share (EPS) PT

Mayora, Tbk, Periode 2011-2020

\begin{tabular}{c|c|c} 
Tahun & Debt to Asset Ratio (DAR) $(\%)$ & Return On Asset (ROA) $(\%)$ \\
\hline 2011 & 7.23 & 85.52 \\
\hline 2,012 & 7.75 & 66.75 \\
\hline 2,013 & 8.94 & 92.76 \\
\hline 2,014 & 9.56 & 91.43 \\
\hline 2,015 & 6.55 & 79.61 \\
\hline 2,016 & 8.28 & 88.54 \\
\hline
\end{tabular}




\begin{tabular}{c|c|c|}
\hline 2,017 & 6.33 & 82.65 \\
\hline 2,018 & 9.41 & 94.55 \\
\hline 2,019 & 10.52 & 99.78 \\
\hline 2020 & 9.52 & 98.55 \\
\hline Rata-rata & 8.41 & 88.01 \\
\hline
\end{tabular}

Berdasarkan data pada tabel di atas, menunjukkan bahwa bahwa sepanjang tahun 2011-2020 pertumbuhan kemampuan perusahaan dalam menghasilkan return laba secara keseluruhan (Return on Assets) rata-rata mengalami perkembangan yang fluktuatif. Persentase pencapaian Return on Assets tertinggi terjadi pada tahun 2019 yang mencapai sebesar $10.52 \%$, sedangkan persentase pencapaian terendah terjadi pada tahun 2015 yang hanya mencapai $6,33 \%$. Secara rata-rata dicapai $8,41 \%$ per tahunnya.

Kondisi serupa juga terjadi pada persentase pencapaian Earning per Share yang perkembangannya dari tahun ke tahun mengalami hal yang serupa. Persentase Earning per Share tertinggi terjadi pada tahun 2019 yakni sebesar Rp 9978 per lembar saham, dan Earning per Share terendah terjadi pada tahun 2012 sebesar Rp 6675 per lembar saham. Secara rata-rata dicapai Rp.8801.

Untuk melihat kinerja perusahaan, investor bisa melihat rasio keuangan untuk dijadikan bahan pertimbangan dalam mengambil keputusan. Invetor juga harus mempertimbangkan faktor-faktor yang dapat mempengaruhi EPS. Pada kesempatan ini peneliti melakukan penelitian tentang analisis penjualan saham perusahaan dengan menggunakan Return on Assets (ROA) sebagai variabel independen dan Earning per share (EPS) sebagai variabel dependen. Untuk itu dilakukan penelitian dengan judul "Analisis Pengaruh Return On Asset Terhadap Earning Per Share Pada PT. Mayora, Tbk Periode 2011-2020".

\section{B. Rumusan Masalah}

1. Bagaimana kondisi Return On Asset pada PT. Mayora, Tbk ?.

2. Bagaimana kondisi Earning Per Share pada PT. Mayora, Tbk ?.

3. Adakah pengaruh Return On Asset terhadap Earning Per Share pada PT. Mayora, Tbk ?.

\section{Tujuan Penelitian}

1. Untuk mengetahui kondisi Return On Asset pada PT. Mayora, Tbk .

2. Untuk mengetahui kondisi Earning Per Share pada PT. Mayora, Tbk .

3. Untuk mengetahui pengaruh Return On Asset terhadap Earning Per Share pada PT. Mayora, Tbk .

\section{METODE PENELITIAN}

\section{Populasi}

\section{Sampel}

Populasi dalam penelitian ini laporan keuangan PT. Mayora, Tbk selama 10 tahun

Teknik pengambilan sampling dalam penelitian ini adalah samplel jenuh, dimana semua anggota populasi dijadikan sebagai sampel. Dengan demikian sampel dalam penelitian ini laporan keuangan PT. Mayora, Tbk selama 10 tahun.

\section{Jenis Penelitian}

Jenis penelitian yang dipakai adalah kuantitatif, dimana tujuannya adalah untuk mengetahui mencari keterhubungan antara variabel independen terhadap variabel dependennya 


\section{Metode Analisis Data}

Dalam menganalisis data digunakan analisis deskriptif, analisis regresi linier sederhana, koefisien korelasi, koefisien determinasi dan uji hipotesis.

\section{HASIL PENELITIAN}

\section{Analisis Deskriptif}

Pada pengujian ini digunakan untuk mengetahui skor minimum dan maksimum skor tertinggi, ratting score dan standar deviasi dari masing-masing variabel. Adapun hasilnya sebagai berikut:

Tabel 2. Hasil Analisis Descriptive Statistics

\section{Descriptive Statistics}

\begin{tabular}{lr|r|r|r|r} 
& $\mathrm{N}$ & \multicolumn{1}{c}{ Minimum } & Maximum & \multicolumn{1}{c}{ Mean } & \multicolumn{1}{c}{ Std. Deviation } \\
\hline ROA & 10 & 6.33 & 10.52 & 8.4090 & 1.41101 \\
\hline EPS & 10 & 66.75 & 99.78 & 88.0140 & 9.91303 \\
\hline Valid N (listwise) & 10 & & & & \\
\hline
\end{tabular}

Return On Asset diperoleh nilai minimum sebesar 6,33\% dan nilai maximum $10,52 \%$ dengan rata-rata sebesar $8,40 \%$ dengan standar deviasi $1,411 \%$. Sedangkan nilai Earning Per Share diperoleh nilai minimum sebesar 6775 dan nilai maximum 9978 dengan rata-rata sebesar 8801 dengan standar deviasi 9,913.

\section{Analisis Kuantitatif}

Pada analisis ini dimaksudkan untuk mengetahui pengaruh variabel independen terhadap variabel dependen. Adapun hasil pengujian sebagai berikut:

\section{a. Analisis Regresi Linier Sederhana}

Uji regresi ini dimaksudkan untuk mengetahui perubahan variabel dependen jika variabel independen mengalami perubahan. Adapun hasil pengujiannya sebagai berikut:

\begin{tabular}{|c|c|c|c|c|c|c|}
\hline \multirow{3}{*}{\multicolumn{2}{|c|}{ Model }} & \multicolumn{4}{|c|}{ Coefficients ${ }^{a}$} & \multirow[b]{3}{*}{ Sig. } \\
\hline & & \multicolumn{2}{|c|}{ Unstandardized Coefficients } & \multirow{2}{*}{$\begin{array}{c}\text { Standardized } \\
\text { Coefficients } \\
\text { Beta }\end{array}$} & \multirow[b]{2}{*}{$\mathrm{t}$} & \\
\hline & & $\mathrm{B}$ & Std. Error & & & \\
\hline 1 & (Constant) & 44.277 & 14.218 & & 3.114 & .014 \\
\hline & ROA & 5.201 & 1.670 & .740 & 3.115 & .014 \\
\hline
\end{tabular}

a. Dependent Variable: EPS

Berdasarkan hasil pengujian pada tabel di atas, diperoleh persamaan regresi $\mathrm{Y}$ $=44,277+5,201 \mathrm{X}$. Dari persamaan tersebut dijelaskan sebagai berikut:

1) Konstanta sebesar 44,277 diartikan jika Return On Asset tidak ada, maka telah terdapat nilai Earning Per Share sebesar 44,277 point.

2) Koefisien regresi Return On Asset sebesar 5,201, angka ini positif artinya setiap ada peningkatan Return On Asset sebesar 5,201 point maka Earning Per Share juga akan mengalami peningkatan sebesar 5,201 point.

\section{b. Analisis Koefisien Korelasi}

Analisis koefisien korelasi dimaksudkan untuk mengetahui tingkat kekuatan hubungan dari variabel independen terhadap variabel dependen. Adapun hasil pengujian sebagai berikut: 
Tabel 4. Hasil Pengujian Koefisien Korelasi Return On Asset Terhadap Earning Per Share.

Correlations $^{b}$

\begin{tabular}{llr|r} 
& & ROA & EPS \\
\hline ROA & Pearson Correlation & 1 & $.740^{*}$ \\
\cline { 2 - 4 } & Sig. (2-tailed) & & .014 \\
\hline EPS & Pearson Correlation & $.740^{*}$ & 1 \\
\cline { 2 - 4 } & Sig. (2-tailed) & .014 & \\
\hline
\end{tabular}

*. Correlation is significant at the 0.05 level (2-tailed).

b. Listwise $\mathrm{N}=10$

Berdasarkan hasil pengujian pada tabel di atas diperoleh nilai korelasi sebesar 0,740 artinya Return On Asset memiliki hubungan yang kuat terhadap Earning Per Share.

\section{c. Analisis Koefisien Determinasi}

Analisis koefisien determinasi dimaksudkan untuk mengetahui besarnya persentase pengaruh dari variabel independen terhadap variabel dependen. Adapun hasil pengujian sebagai berikut:

Tabel 5. Hasil Pengujian Koefisien Determinasi Return On Asset Terhadap

Earning Per Share.

Model Summary

\begin{tabular}{|c|c|c|c|c|}
\hline \\
\hline Model & $\mathrm{R}$ & R Square & $\begin{array}{c}\text { Adjusted R } \\
\text { Square }\end{array}$ & Std. Error of the Estimate \\
\hline 1 & $.740^{\mathrm{a}}$ & .548 & .492 & 7.06812 \\
\hline
\end{tabular}

Berdasarkan hasil pengujian pada tabel di atas diperoleh nilai determinasi sebesar 0,548 artinya Return On Asset memiliki kontribusi pengaruh sebesar 54,8\% terhadap Earning Per Share, sedangkan sisanya sebesar 45,2\% dipengaruhi faktor lain.

\section{d. Uji Hipotesis}

Pengujian hipotesis dengan uji t digunakan untuk mengetahui hipotesis mana yang diterima. Rumusan hipotesis: Terdapat pengaruh yang signifikan Return On Asset terhadap Earning Per Share.

Tabel 6. Hasil Uji Hipotesis Return On Asset Terhadap Earning Per Share.

\begin{tabular}{|c|c|c|c|c|c|c|}
\hline \multicolumn{7}{|c|}{ Coefficients ${ }^{\mathrm{a}}$} \\
\hline \multirow{2}{*}{\multicolumn{2}{|c|}{ Model }} & \multicolumn{2}{|c|}{ Unstandardized Coefficients } & \multirow{2}{*}{$\begin{array}{l}\text { Standardized } \\
\text { Coefficients } \\
\text { Beta }\end{array}$} & \multirow[b]{2}{*}{$\mathrm{t}$} & \multirow[b]{2}{*}{ Sig. } \\
\hline & & B & Std. Error & & & \\
\hline 1 & (Constant) & 44.277 & 14.218 & & 3.114 & .014 \\
\hline & ROA & 5.201 & 1.670 & .740 & 3.115 & .014 \\
\hline
\end{tabular}

a. Dependent Variable: EPS

Berdasarkan hasil pengujian pada tabel di atas, diperoleh nilai $\mathrm{t}$ hitung $>\mathrm{t}$ tabel atau $(3,115>2,306)$, dengan demikian hipotesis yang diajukan bahwa terdapat pengaruh yang signifikan Return On Asset terhadap Earning Per Share diterima.

\section{PEMBAHASAN HASIL PENELITIAN}

\section{Kondisi Nilai Variabel Return On Asset}

Berdasarkan data empiris pada tabel di atas dan analisis data, variabel Return On Asset dari data laporan keuangan selama 10 tahun diperoleh nilai rata-rata per tahun sebesar $8,40 \%$. 


\section{Kondisi Nilai Variabel Earning Per Share}

Berdasarkan data empiris pada tabel di atas dan analisis data, variabel Earning Per Share dari data laporan keuangan selama 10 tahun diperoleh nilai rata-rata per tahun sebesar $39,06 \%$.

\section{Pengaruh Return On Asset Terhadap Earning Per Share}

Return On Asset berpengaruh signifikan terhadap Earning Per Share dengan persamaan regresi $\mathrm{Y}=44,277+5,201 \mathrm{X}$, nilai korelasi sebesar 0,740 atau memiliki hubungan yang kuat dengan kontribusi pengaruh sebesar 54,8\%, sedangkan sisanya sebesar $45,2 \%$ dipengaruhi oleh faktor lain yang tidak dilakukan penelitian. Pengujian hipotesis diperoleh nilai $t$ hitung $>\mathrm{t}$ tabel atau $(3,115>2,306)$. Dengan demikian hipotesis yang diajukan bahwa terdapat berpengaruh yang signifikan antara Return On Asset terhadap Earning Per Share pada PT. Mayora, Tbk diterima.

\section{KESIMPULAN DAN SARAN}

\section{Kesimpulan}

a. Kondisi variabel Return On Asset berdasar pada periode laporan keuangan 10 tahun diperoleh Return On Asset rata-rata sebesar 8,40\%.

b. Kondisi variabel Earning Per Share berdasar pada periode laporan keuangan 10 tahun diperoleh Return On Asset rata-rata sebesar 39,06\%.

c. Return On Asset berpengaruh signifikan terhadap Earning Per Share dengan persamaan regresi $\mathrm{Y}=44,277+5,201 \mathrm{X}$, nilai korelasi sebesar 0,740 atau kuat dan kontribusi pengaruh sebesar 54,8\% sedangkan sisanya sebesar 45,2\% dipengaruhi faktor lain. Uji hipotesis diperoleh nilai $t$ hitung > t tabel atau $(3,115>2,306)$.

\section{Saran}

Berdasarkan hasil penelitian yang sudah disimpulkan, maka penulis memberikan saran sebagai berikut:

a. Profitabilitas dengan proksi return on asset (ROA) pada perusahaan yang diteliti mengalami fluktuatif. Hal ini mengindikasikan bahwa kemampuan manajemen perusahaan dalam menghasilkan laba perusahaan berdasarkan kegunaan aset yang dimiliki belum stabil. Oleh karenaitu, harus dapat memaksimalkan kinerja sehingga meningkatkan laba.

b. Earning per share (EPS) perusahaan yang diteliti mengalami penurunan. Hal ni disebabkan kinerja perusahaan yang menurun sehingga nilai EPS pun ikut menurun. Penurunan EPS pada perusahaan ini akan menurunkan harga saham perusahaan. Selain itu ketertarikan investor untuk menanamkan modalnya pada perusahaan juga akan berkurang

\section{DAFTAR PUSTAKA}

Agus Harjito \& Martono, (2015) "Manajemen Keuangan" Yogyakarta: Penerbit Ekonisia. Agus Sartono. (2016). "Manajemen Keuangan Toeri dan Aplikasi", Edisi keempat, Yogyakarta: Penerbit BPFE.

Algifari. (2015). "Analisis Regresi untuk Bisnis dan Ekonomi”. Yogyakarta: BPFE.

Arikunto, Suharsimi (2014). "Prosedur Penelitian Suatu Pendekatan Praktek". Jakarta: Rineka Cipta.

Bambang Riyanto, (2011). "Dasar-dasar Pembelanjaan Perusahaan". Edisi ke empat, Yogyakarta: BPFE.

Fahmi, Irham (2012), "Pengantar Manajemen Keuangan” Cetakan pertama. Bandung: Penerbit Alfabeta. 
Imam Ghozali (2017). "Aplikasi Analisis Multivariate Dengan Program SPSS”. Edisi Kelima. Semarang: Badan Penerbit Undip.

Istijanto (2014) "Riset Sumber Daya Manusia". Jakarta: PT. Gramedia Pustaka

Jasmani, J. (2018). Pengaruh Kinerja Keuangan Terhadap Harga Saham (Analisis Pada Perusahaan Property dan Real Estate Yang Go Public di Bursa Efek Indonesia. Jurnal Akuntansi Indonesia, 12(2).

Jasmani, J. (2019). The Effect of Liquidity and Working Capital Turnover on Profitability at PT. Sumber Cipta Multiniaga, South Jakarta. PINISI Discretion Review, 3(1), 2938.

Kasmir. (2012) "Pengantar Manajemen Keuangan”, Edisi Pertama, Cetakan kedua, Jakarta: Prenada Media.

Kharis, Ismu Fadli (2011). "Studi Mengenai Impulse Buying dalam Penjualan Online". Semarang : Skripsi Universitas Diponegoro

Martono dan Agus Harjito, (2011). "Manajemen Keuangan”, Jakarta: Penerbit Ekonisia.

Munawir (2010), “Analisis Laporan Keuangan”, Edisi Ke Empat, Yogyakarta: Penerbit Liberty.

Santoso, Singgih (2015). "Menguasai Statistik Multivariat". Jakarta: PT Elex Media Komputindo.

Sartono, "Manajemen Keuangan Aplikasi Dan Teori", Edisi Keempat, BPFE, Yogyakarta, 2008.

Sawir, (2003). "Analisis Kinerja Keuangan dan Perencanaan Keuangan Perusahaan", Cetakan ketiga, Jakarta: Penerbit PT. Gramedia Pustaka Utama.

Sugiyarso, G. dan F. Winarni, "Manajemen Keuangan (Pemahaman Laporan Keuangan, Pengelolaan Aktiva, Kewajiban dan Modal serta Pengukuran

Sugiyono (2017), "Metode Penelitian Administrasi : dilengkapi dengan Metode R \& D". Bandung: Alfabeta. 